\title{
THE CONCEPT OF EXTRACTIVE WASTE
}

\author{
Filip Nawrot*
}

\section{ABSTRACT}

The analysis of the concept of extractive waste is the main point of this paper. This matter is interesting because it is connected both with the geological and mining law as well as with the "waste law".

In the first part of the paper some remarks about the definition of waste from the Act on Waste are made. In this part the relation between the definition of waste and the definition of extractive waste, which can be found in the Act on Extractive Waste, is also presented. Afterwards other concepts used in the definition of extractive waste are analysed. Some exceptions in which provisions of the Act on Extractive Waste do not apply are discussed in the last part.

Key words: extractive waste, concept, waste, waste law, the Geological and Mining Law

\section{INTRODUCTION}

The analysis of the concept of extractive waste is the main point of this paper. This matter is interesting because it is connected both with the geological and mining law as well as the "waste law". What is more, extractive

* Department of Mining Law and Environmental Protection Law, The Faculty of Law and Administration at the University of Silesia, filip.nawrot@yahoo.pl.

${ }^{1}$ Because of the growth of the regulations concerning waste in the recent years, voices are being raised in the literature that it is possible to talk about "law concerning law", 
waste is a big percentage of waste produced in Poland nowadays ${ }^{2}$. Considerations concerning extractive waste's status in Polish law were made both before and after the Act of 10 July 2008 on Extractive Waste ${ }^{3}$ was passed, just to mention G. Dobrowolski ${ }^{4}$, A. Lipiński ${ }^{5}$, J. Jerzmański ${ }^{6}$, A. Barczak and A. Kaźmierska-Patrzyczna ${ }^{7}$ or W. Gapiński ${ }^{8}$. However, these papers, especially W. Gapiński's paper concerning the concept of extractive waste, were created before the new Act of 14 December 2012 on Waste ${ }^{9}$ and the new Act of 9 June 2011 - the Geological and Mining Law ${ }^{10}$ was even passed and before the changes of the Act on Extractive Waste itself. That is why, it is worth analysing this topic again in order to update some of the conclusions and to refer to the current jurisdiction.

It is necessary to quote the definition of extractive waste, which can be found in the article 3 item 1 point 7 AEW. According to this defini-

"waste law" or "waste management law" (Grzegorz Dobrowolski, "Rozwój ustawodawstwa dotyczącego odpadów innych niż komunalne”, Przegląd Prawa Ochrony Środowiska 3(2013): 27; Wojciech Radecki, Ustawa o odpadach. Komentarz, Warszawa: Wolters Kluwer, 2016, 76).

${ }^{2}$ According to the data from the Polish Geological Institute in 2010 extractive waste was $50 \%$ of waste produced in Poland. January 14, 2018 http://geoportal.pgi.gov.pl/ odpady.

${ }^{3}$ Journal of Laws of 2017 item 1849 (further referred to as: the Act on Extractive Waste or AEW).

${ }^{4}$ Grzegorz Dobrowolski, "Skała płonna jako szczególny rodzaj odpadu”, In: Prawo i polityka w ochronie środowiska: studia z okazji 40-lecia pracy naukowej Jerzego Sommera, ed. Halina Lisicka, Wrocław: Wydawnictwo Prawa Ochrony Środowiska, 49-54.

${ }^{5}$ Aleksander Lipiński, "Nowe zasady postępowania z odpadami wydobywczymi” In: Aktualne problemy prawa ochrony środowiska 2008, ed. Grzegorz Dobrowolski, Katowice: Ecausa, 2008, 93-101.

${ }^{6}$ Jan Jerzmański, "Status prawny mas ziemnych i skalnych w Polsce oraz UE”, In: Prawna regulacja geologii i górnictwa w Polsce, Czechach i na Słowacji. Wybrane zagadnienia, ed. Grzegorz Dobrowolski, Katowice: [Infomax, Marasik-Bielejec, E., Bielejec, G.], 2014, 262-267.

${ }^{7}$ Anna Barczak, Aneta Kaźmierska-Patrzyczna, "Gospodarowanie odpadami w górnictwie”, In: Prawna..., 229-239.

${ }^{8}$ Wojciech Gapiński, "Pojęcie odpadu wydobywczego - analiza prawna”, Bezpieczeństwo Pracy i Ochrona Środowiska w Górnictwie 1(2011): 14-22 .

${ }^{9}$ Journal of Laws of 2018 item 21 (further referred to as: the Act on Waste or AW).

${ }^{10}$ Journal of Laws of 2017 item 2126 (further referred to as: the Geological and Mining Law or GML). 
tion, extractive waste is the waste coming from the prospecting, exploring, extraction, treatment and storage of minerals from deposit. This definition is very similar to the one which can be found in the article 2 item 1 of the Directive 2006/21/EC of the European Parliament and the Council of 15 March 2006 on the management of waste from extractive industries and amending Directive 2004/35/EC $\mathrm{EC}^{11}$. According to the above mentioned article, this Directive covers the management of waste resulting from the prospecting, extraction, treatment and storage of mineral resources and the working of quarries, hereinafter 'extractive waste'. The definition which can be found in the Polish law is at first glance clear and transparent. But after commencing a deeper analysis, it raises a number of interpretational doubts.

In the first part of the paper some considerations about the definition of waste from the Act on Waste are made. In this part the relation between the definition of waste and the definition of extractive waste, which can be found in the Act on Extractive Waste, in article 3 item 1 point 7 AEW, is also presented. Afterwards other concepts used in the definition of extractive waste are analysed. The exceptions to which provisions of the Act on Extractive Waste do not apply are discussed in the last part of this paper.

\section{DEFINITION OF WASTE}

The present definition of waste can be found in the Act on Waste and it is a reflection of the definition presented in the Directive 2008/98/ EC of the European Parliament and the Council of $19^{\text {th }}$ November 2008 on waste and repealing certain Directives ${ }^{12}$. According to article 3 item 1 point $6 \mathrm{AW}$, waste is any substance or object which the holder discards or intends or is required to discard. This definition is almost the same

${ }^{11}$ OJ L 102, 11.4.2006, p. 15-34 (further referred to as: the Directive on Extractive Waste or DEW).

${ }^{12}$ OJ L 312, 22.11.2008, p. 3-30 (further referred to as: the Directive on Waste or DW). 
as it was in the Act of $27^{\text {th }}$ April 2001 on Waste ${ }^{13}$, however the legislator decided not to refer to the attachment with the categories of waste, which seems to be a justified change ${ }^{14}$.

The above mentioned definition has still been creating many interpretative difficulties. The meaning of "discard" and a subjective factor included in this definition are problematic. The legislator does not specify the concept of "discarding" and that is why, it is necessary to fall back to the common understanding of this concept, to the extensive literature in this field $^{15}$, as well as to the latest jurisdiction.

According to the Polish Language Dictionary, the concept "discarding" means release of something unnecessary, burdensome or release of somebody's undesirable presence ${ }^{16}$. The latest administrative courts' judgments indicate that the qualification of certain object to be a waste is arbitrated by the premise of discarding, which can be physical, intended or commanded activity. That premise can be stated only on the basis of an activity of that object's holder, including objective circumstances which allows reproducing their intentions towards the object. The point is not losing control over the object, but the substantial change of its usage, different from the main purpose, for which it becomes unusable, especially when the change could cause negative consequences to the human or the environment. Discarding an object is also disposing (selling) it to another entity, which will use it in an essentially different way than the previous one. This means that objects which are again the subject of further economic use and therefore become the object of commercial transactions as a good with specific economic value, could be classified as waste ${ }^{17}$.

${ }^{13}$ The Act of 27 December 2012 on Waste, Journal of Laws No.62 item 628 - act is no longer in force (further referred to as: the Act on Waste of 2001).

${ }^{14}$ Bartosz Rakoczy, In: Ustawa o odpadach. Komentarz, ed. Bartosz Rakoczy, Warszawa: LexisNexis Polska Sp. z o.o., 2013, 25.

${ }^{15}$ See inter alia: Bartosz Rakoczy, In: Ustawa...; Wojciech Radecki, Ustawa...; Zbigniew Bukowski, Prawo gospodarki odpadami, Poznań: Polskie Zrzeszenie Inżynierów i Techników Sanitarnych. Oddział Wielkopolski, 2014; Piotr Korzeniowski, Model prawny systemu gospodarki odpadami. Studium administracyjno-prawne, Łódź: Wydawnictwo Uniwersytetu Łódzkiego, 2014.

${ }^{16}$ Polish Language On-line Dictionary. January 14, 2018 https://sjp.pwn.pl/szukaj/ pozbywa $\%$ C4\%87\%20si\%C4\%99.html.

${ }^{17}$ Judgment of Supreme Administrative Court of $16^{\text {th }}$ September 2015, II OSK 2920/13, Legalis number 1362458. Cf. Judgment of Supreme Administrative Court of 
Also in the Guidance for the interpretation of the key provisions of Directive 2008/98/EC on waste it is underlined that the meaning of the concept "discarding" is crucial to understand fully the definition of waste. In this Guidance three alternatives of "discard" are described. The first one concerns an action or activity of the holder of the substance or the object, like throwing an item into a waste bin. The second alternative describes an intention of the holder, as an example, one can indicate a company's decision to send off for appropriate disposal or recovery any of its stock of raw materials that cannot be returned to the manufacturer due to their closing down. The last alternative is a legal obligation, where provisions of EU PCB/PCT Directive 96/59/EC can be mentioned. Under these provisions any oil containing PCBs above 50 ppm must be discarded and is therefore to be considered waste ${ }^{18}$.

The subjective factor causes vagueness of the concept of waste. It manifests in the fact, that a waste producer (holder) estimates if a given substance or object is a waste. This estimation can be lately verified by competent administrative authorities ${ }^{19}$. What is important, producer (holder) does not have a complete freedom in this matter ${ }^{20}$. The limits of that freedom can be divided into: a technological factor, economic factor and the aspect of the environmental protection ${ }^{21}$.

After the above analysis of the concept of waste, some consideration should be given to the relationship between the definition of waste and the definition of extractive waste. However, it is not a difficult task, because according to the Act on Extractive Waste and its article 1 item 3 AEW, in the cases not regulated in this act, the provisions of the Act on Waste

$27^{\text {th }}$ January 2017, II OSK 1171/15, Legalis number 1604828; Judgment of Supreme Administrative Court of $11^{\text {th }}$ May 2017, II OSK 2274/15, Legalis number 1632616; Judgment of Supreme Administrative Court of $22^{\text {nd }}$ March 2017, II FSK 522/15, Legalis number 1605761.

${ }^{18}$ Guidance on the interpretation of key provisions of Directive 2008/98/EC on waste. January 14, 2018 http://ec.europa.eu/environment/waste/framework/pdf/guidance_doc.pdf.

${ }^{19}$ Aneta Pacek-Łopalewska, Ustawa o odpadach. Komentarz, Wrocław: Presscom Sp. z o.o., 2013, 45.

${ }^{20}$ Wojciech Gapiński, Pojęcie..., 17.

${ }^{21}$ Bartosz Draniewicz, "Własność odpadów w prawie polskim - analiza prawna", Przegląd Ustawodawstwa Gospodarczego 11(2006): 25. 
are to be applied. Therefore, the concept of "waste" used in the Act on Extractive Waste should be understood in the same way as in the Act on Waste $^{22}$. Consequently, the considerations made at the beginning of this paper has become adequate. Not only will the definition of waste apply to extractive waste, but also other provisions of the Act on Waste. What is interesting, as J. Jerzmański points, the Polish solution is different from the European one. The Directive on Extractive Waste refers to the Directive on Waste only in the range of definition of waste. According to Article 2 item 3 point d) DW, extractive waste shall be excluded from the scope of this Directive. Certain irregularity is noticeable in the implementation of European regulations to the Polish law system ${ }^{23}$.

Comparing to the previous legislation, a major novelty is introduced, which is the possible classification of certain objects and substances coming from a human activity, indicated in the definition of extractive waste, as by-products. The definition of by-products is introduced in article 10 AW, according to which a substance or object, resulting from a production process, whose primary aim is not the production of that item itself, may be regarded as not being waste but as being a by-product, if the following conditions specified in this article are fulfilled. Among them are mentioned: further use of the substance or object is certain; the substance or object can be used directly without any further processing other than normal industrial practice; the substance or object is produced as an integral part of a production process; the substance or object fulfills all relevant product, environmental and health protection requirements (including legal requirements) for the specific use and will not lead to overall adverse environmental or human health impact ${ }^{24}$. This definition is favorable in case of extractive waste prevention which is usually very hard to perform, but they can be used in future, for example in the construction sector. Crushed fill-up which is sand with a $0-2 \mathrm{~mm}$ fraction can be an example of by-product among mineral aggregates ${ }^{25}$.

${ }^{22}$ After Wojciech Gapiński, Pojęcie..., 18.

${ }^{23}$ Jan Jerzmański, Status..., 265.

${ }^{24}$ Aneta Pacek-Łopalewska, Ustawa..., 70-71.

${ }^{25}$ Maciej Stachowski, “Gospodarka odpadami wydobywczymi”, Kruszywa 4(2014): 40. 


\section{OTHER COMPONENTS OF THE DEFINITION}

OF EXTRACTIVE WASTE

The next step in the interpretation of the concept of extractive waste is the analysis of other terms presented in the analyzed definition. It should be noticed that the definition specifies the concept of waste from the Act on Waste, by indicating the sources of producing extractive waste. However, not all terms indicating these sources are defined in the Polish legal system.

Reference to the Geological and Mining Law enables to explain some terms mentioned above. It is necessary to start with certain remarks about the concept of mineral. The Act on Extractive Waste in article 3 item 1 point $3 \mathrm{AEW}$ refers to the Geological and Mining Law in this matter, at the same time excluding brine, curative and thermal waters from the concept of mineral. Nevertheless, what is interesting, the Geological and Mining Law does not include the definition of mineral, as it only explains how to understand extracted mineral and mineral deposit. Several attempts to define minerals have been made. For example H. Schwarz, on the basis of mineral deposit's definition from article 6 point 19 GML, formulates a definition of mineral as minerals and rocks and other liquid, gas and solid natural substances. However, the author draws attention to an imperfection of this definition because of insufficient description of constitutive features $^{26}$. A Lipiński cites also a language definition, according to which mineral is a rock (within the meaning of geological sciences) or a part of it separated during exploitation or liquid or gas included in it, which becomes a useful mineral resource after extraction in natural shape or after being processed. But the author also states that each mineral (substance) existing in natural deposit could be called mineral, and its utility might be only a reason to begin its extraction.

The concepts of prospecting and exploring used in the definition of extractive waste raise nearly no interpretative doubts, because they are defined in the Geological and Mining Law. The definition of prospecting

${ }^{26}$ Hubert Schwarz, Prawo geologiczne i górnicze. Komentarz. Vol. 1 (art. 1-103), Wrocław: Salome, 2012, 69. 
from article 6 item 1 point 7 GML is a modified regulation, which was present in the Geological and Mining Law from $1994^{27}$. According to it, "to prospect" means "to carry out" geological development works aimed at detection and preliminary documentation of mineral or underground water deposit, or underground carbon dioxide storage complex. The usage of conjunction implies that only combined presence of the aims of detection together with preliminary documentation of deposit fulfills the conditions specified in this article. However, it should be noted that this article mentions an "aim" not a "result" of works. So, even when the results are not achieved, but a planned aim including detection and preliminary documentation of deposit is, these works will be classified as prospecting ${ }^{28}$. Nevertheless, some interpretation doubts are raised by the term "preliminary documentation of deposit". In the literature it is stated that this condition is fulfilled by geological documentation prepared with the precision which is not sufficient to start an activity ${ }^{29}$. It is worth reminding that some underground waters are excluded from the concept of mineral in the Act on Extractive Waste.

According to article 6 item 1 point 13 GML, "to explore" means "to carry out" geological development works in the area of preliminary-documented mineral or underground water deposits, or underground carbon dioxide storage complex. It is the next stage of geological development works, after prospecting, which is a result of the mineral's discovery. It can be carried out either after preparing geological documentation, which is a part of prospecting, or it can be carried out together with prospecting. It is possible because one concession for both prospecting and exploring can be obtained ${ }^{30}$. This definition can also raise interpretative doubts, which is pointed in the literature. First of all, one cannot state that exploring means performing all geological development works in the preliminary-documented area. This applies, in particular, to these works which are not con-

${ }^{27}$ The Act of $4^{\text {th }}$ February 1994 - Geological and Mining Law, Journal of Laws No. 228 item 1947 - act is no longer in force.

${ }^{28}$ Hubert Schwarz, Prawo..., 75.

${ }^{29}$ Aleksander Lipiński, Ryszard Mikosz, Komentarz. Ustawa prawo geologiczne i górnicze, Warszawa: Dom Wydawniczy ABC, 2003, 44-45.

${ }^{30}$ Hubert Schwarz, Prawo..., 79-80. 
nected with preliminary documentation, which is mentioned in this point of article 6. Geophysical works connected with exploring of hydrocarbons at the real estate, where documented deposit of sand is located, can be shown as an example. According to A. Lipiński, geological development works can be classified as an exploration only when they aim at exploring deeply the structure which was an object of previous research ${ }^{31}$. It is again worth reminding that some underground waters are excluded from the concept of mineral in the Act on Extractive Waste.

Extracting minerals is the next activity which results in producing extractive waste, but this term was not defined neither in the present Geological and Mining Law nor in a previous act from 1994, despite the fact that extracting minerals from deposit is essential for the whole act, which again is pointed in the literature ${ }^{32}$. Recently added definition of the exploring of hydrocarbons can be mentioned, but it does not help to understand the concept of extraction ${ }^{33}$. In some judgments the administrative courts refer to the language definition of extraction, for example Supreme Administrative Court in the judgment of $7^{\text {th }}$ December $2012^{34}$. As A. Lipiński states, the extraction of minerals is separating mineral or other substance from their natural deposit, but only when the main aim of that activity is obtaining this mineral or other substances. On the occasion of these reflections, the examples of situations when this result is present, but the main aim of these works is not an extraction of a mineral can be

${ }^{31}$ Aleksander Lipiński, "Komentarz do art. 6 - 9 ustawy z dnia 9 czerwca 2011 r. Prawo geologiczne i górnicze”, Prawne Problemy Górnictwa i Ochrony Środowiska 1(2017), 21 .

${ }^{32}$ Aleksander Lipiński, "Zakres i przedmiot Prawa geologicznego i górniczego", In: Zrównoważony rozwój jako czynnik determinujący prawne podstawy zarządzania geologicznymi zasobami środowiska, ed. Grzegorz Dobrowolski, Katowice: Agencja Reklamowa TOP, 2016, 42.

${ }^{33}$ According to the definition from article 6 item 1 point $16 \mathrm{c}$ GML, exploring of hydrocarbons form deposit is mining, including preparing extracted hydrocarbons for transport and their transport within the mining plant.

${ }^{34}$ See II FSK 2407/12, Central Database of Administrative Courts Judgments. January 14, 2018 http://orzeczenia.nsa.gov.pl/doc/061D0C4D88. According to the mentioned definition, extraction is getting out from the inside to the surface, pulling out, eventually squeezing something out of somebody (Słownik języka polskiego, ed. Mieczysław Szymczak, Warszawa: Państwowe Wydawnictwo Naukowe, 1981, 794-795). 
mentioned, like trench excavation ${ }^{35}$. It is necessary to keep in mind that extraction does not always require obtaining a concession, because according to article $4 \mathrm{GML}$, extraction intended to satisfy a natural person's own needs is permitted, after compliance with the appropriate conditions stated in this article ${ }^{36}$. Activity in open-cast mining plants is also extraction, thus the working of quarries indicated in the Directive on Extractive Waste fall within the concept of extraction.

Treatment is the only source of producing extractive waste defined in the Act on Extractive Waste, and according to article 3 item 1 point 10 AEW treatment means mechanical, physical, biological, thermal or chemical process or combination of processes carried out on extracted minerals with a view to prepare them to be used, including size change, classification, separation and leaching, and the re-processing of previously discarded waste, but excluding smelting, thermal manufacturing processes (other than the burning of limestone) and metallurgical processes. This definition is a reflection of the definition from the Directive on Extractive Waste, which can be found in Article 3 point $8 \mathrm{DEW}$. It is worth mentioning that both the directive and the Polish act distinctly define a type of extractive waste - tailings. It is defined as the waste solids or slurries which remain after the treatment of minerals, by mechanical, physical, biological, thermal or chemical process or the combination of processes.

Storage is the last human's activity connected with the production of extractive waste. The present definition of storage can be found in article 3 item 1 point $5 \mathrm{AW}$, and it is applied to as the temporary waste keeping. This definition is similar to the one from the previously binding Act on Waste of 2001, which defined storage as a temporary keeping or gathering of waste. However, in the present act, in order to avoid interpretative doubts, it is stated in the next part of this article, that storage is carried out only: during generation of waste, as a preliminary storage by a waste producer; during collection, as a temporary storage of waste by a collector (this kind of "storage" is "collecting" according to the definition of collecting); during treatment, as storing by a waste

\footnotetext{
${ }^{35}$ Aleksander Lipiński, Zakres..., 42.

${ }^{36}$ Aleksander Lipiński, Zakres..., 43-47.
} 
treatment operator ${ }^{37}$. It seems that in the case of extractive waste the first of the above mentioned meanings (preliminary storage by a waste producer) is appropriate. It must be emphasized, which is underlined in jurisdiction, that storage is not an independent form of the management of waste and always it is a part of bigger process - generation, collection or treatment of waste $e^{38}$. According to its definition, storage is characterized by its temporality. Except the definition, other regulations from the Act on Waste concerning storage will not be applied to extractive waste, because under the provisions of art. 1 item 3 AEW, Division II Chapter 7 will be excluded.

\section{SCOPE OF REGULATIONS OF THE ACT ON EXTRACTIVE WASTE}

Worth considering is if all soil and rock masses produced in the processes mentioned in analyzed definition are extractive waste. Before the present acts, which are currently governing their status, came into force, this matter had been regulated by the Act on Waste of 2001 and the Council Directive 75/442/EEC of 15 July 1975 on waste ${ }^{39}$. They both led to doubts about the status of soil and rock masses. The solution turned out to be to refer to the conception of "technological process" 40 and jurisdiction of the Court of Justice of the European Communities.

In the cases of Avesta Polarit ${ }^{41}$ and Palin Granit ${ }^{42}$ the Court was about to decide in what circumstances leftover rock from mining and quarry-

${ }^{37}$ Ustawa o odpadach. Komentarz, ed. Aneta Mostowska, Warszawa: C.H. Beck, 2014, 20-21.

38 Judgment of Voivodship Administrative Court in Cracow of $22^{\text {nd }}$ September 2016, II SA/Kr 748/16, Legalis number 1542968.

${ }^{39}$ OJ L 194, 25.7.1975, special edition in Polish: Chapter 15 Volume 001 p. 23-25.

${ }^{40}$ Grzegorz Dobrowolski, Skała..., 51.

${ }^{41}$ Judgment of the Court of Justice of the European Communities of $11^{\text {th }}$ September 2003, AvestaPolarit Chrome Oy, Case C-114/01. January 14, 2018http://curia.europa. eu/juris/document/document.jsf?text=\&docid=48565\&pageIndex=0\&doclang=EN\&mode $=1$ st $\&$ dir $=\&$ occ $=$ first $\&$ part $=1 \&$ cid $=690002$.

42 Judgment of the Court of Justice of the European Communities of $18^{\text {th }}$ Aprli 2002, Palin Granit Oy, Case C-9/00. January 14, 2018 http://curia.europa.eu/juris/document/ 
ing should be considered as waste. The Court stated that where the rocks were being stored prior to a possible future use or a future waste treatment obligation, they would be waste. If certain residues that could be physically identified were being stored prior to a potential but not certain re-use, without being processed, in order to fill in underground galleries for stability purposes, as required for the principal activity of the mine (extraction of ore), they would not be waste ${ }^{43}$.

In the case against the Italian Republic the Court's judgment was a little bit different ${ }^{44}$. The subject matter of the ruling was national provisions excluding from the scope of the national legislation relating to waste, excavated earth and rocks intended for actual re-use for filling, backfilling, embanking or as aggregates (with some exceptions). In the procedure, which was initiated by the European Commission, the Italian Republic contends that the materials covered by the provisions at issue may be regarded, in accordance with the case-law of the Court, not as excavation residue, but as a by-product. The Court stated that, although in some cases that may actually reflect the true position, there cannot be a general presumption that excavated earth and rocks are by-products.

In the current legislative framework it is necessary to refer to article 2 AEW, which indicates five categories of exceptions, to which provisions of the Act on Extractive Waste do not apply. The first category includes waste resulting from prospecting, exploring, extraction of minerals from deposits and their treatment and storage, which is not directly connected with the above mentioned activities. The second category includes waste resulting from prospecting, exploring, extraction minerals from deposits and their treatment from the maritime area of the Republic of Poland, while the

document.jsf?text $=\&$ docid $=47274 \&$ pageIndex $=0 \&$ doclang $=$ EN $\&$ mode $=1$ st $\&$ dir $=\&$ occ $=-$ first $\&$ part $=1 \&$ cid $=690165$.

${ }_{43}$ Communication from the Commission to the Council and the European Parliament on the Interpretative Communication on waste and by-products. January 14, 2018 http://eur-lex.europa.eu/legal-content/PL/ALL/?uri=CELEX\%3A52007DC0059.

${ }^{44}$ Judgment of the Court of Justice of the European Communities of $18^{\text {th }}$ December 2007 , Commission of theEuropean Communitiesvitalian Republic, CaseC-194/05.January 14,2018 http://curia.europa.eu/juris/document/document.jsf;jsessionid=9ea7d0f130d55a2bfdea49f141e782cbe97b87223a8d.e34KaxiLc3eQc40LaxqMbN4PaNePe0?text=\&docid=71918\&p ageIndex=0\&doclang=PL\&mode=1st \&dir $=\& o c c=$ first $\&$ part $=1 \&$ cid $=686194$. 
third one includes forcing the water into the rock mass in the meaning of Geological and Mining Law.

The last two categories mentioned in this article are worth discussing. The Act on Extractive Waste does not apply to soil and rock masses moved in the connection with extraction of minerals from deposits, if either a concession for extraction of minerals from a deposit, or the operational plan of a mining plant approved by the decisions mentioned in the Geological and Mining Law or a local spatial development plan for mining land, determines conditions and the way they are managed. Provisions of the act do not also apply to overburden, which is soil and rock masses which are removed from the above deposits in order to enable to extract a useful mineral, dumped on a mining area, if it is not waste within the meaning of the Act on Waste and with a term and way of its management determined in compliance of provisions of the Geological and mining law concerning operation of mining plan.

Soil and rock masses mentioned in article 2 item 1 point $4 \mathrm{AEW}$ and article 2 point $11 \mathrm{AW}$ are excluded from the scope of the both acts. But they are still waste according to the Act on Waste ${ }^{45}$.

Legal status of overburden is more complicated and under the regulations of the Act on Waste from 2001 it was not regarded as waste. As a result of the entry of amendments to the Act on Extractive Waste in December 2012 and a shortcoming in a harmonized provisions of the new Act on Waste from 2012 and the Act on Extractive Waste, interpretative doubts may arise within the meaning of exclusion from article 2 item 1 point $5 \mathrm{AEW}$. It seems to be correct to follow the W. Radecki's interpretation: If a term and way of management of the overburden were specified in an approved operational plan of a mining plant, then neither provisions of the Act on Waste nor the provisions of the Act on Extractive Waste apply to overburden. If it were otherwise, then there would be a contradiction between article 2 point $11 \mathrm{AW}$ and article 2 item 1 point $5 \mathrm{AEW}(. .$.$) . The consequences of$ such conclusions are essential. Irrespective of the fact that overburden is moved within the underground mine working (...) or moved outside the underground mine working (...), provisions of the Act on Waste will not apply to it, if a way

${ }^{45}$ Wojciech Radecki, Ustawa..., 95-96. 
of management of overburden was determined in approved operational plan of a mining plant ${ }^{46}$.

It is worth considering how to understand the concept of "management" used in the provisions mentioned above. The legislator does not give any guidance in this matter. Also referring to the definition of the management of waste from article 3 item 1 point $2 \mathrm{AW}$ is not satisfying, especially because provisions of the Act on Waste do not apply to these soil and rock masses. The most appropriate solution is to understand "management" as "usage".

The jurisdiction concerning exceptions to which provisions of the Act on Extractive Waste do not apply is limited. The judgment of Voivodship Administrative Court in Szczecin of $4^{\text {th }}$ December 2014 can be shown as an example ${ }^{47}$. After controlling, Voivodship Inspectorate for Environmental Protection stated irregularities on an estate, on which there used to be a mining plant. These irregularities were connected with the compliance with the environmental protection requirements and they included the management of extractive waste without an extractive waste management program and required decision of a competent authority approving this program and also storing of extractive waste longer than 3 years. Heaps of sand were located on that estate, so Voivodship Inspectorate for Environmental Protection ordered to initiate steps in order to regulate legal status concerning the management of extractive waste.

In a claim to Voivodship Administrative Court, the owner of the estate states that this sand is not extractive waste, because it had not been waste before he purchased it, and it is not any substance or object which he discards or intends or is required to discard. Sand is described as a valuable material, used by him during pursuing economic activity. It is used to carry out works and to provide services in the area of clearance the roads' surface during winter and as a material for reclamation.

The case files prove that sand was produced as a result of the treatment of extracted mineral, so according to Voivodship Administrative Court in Szczecin, there are no doubts that this sand is extractive waste. Also, not all of the premises from article 2 item 1 point $4 \mathrm{AEW}$ did occur, which could

\footnotetext{
46 Wojciech Radecki, Ustawa..., 108-109. Also see: Jan Jerzmański, Status..., 266.

${ }^{47}$ II SA/Sz 494/14, Legalis number 1182299.
} 
exclude applying regulations of the Act on Extractive Waste to this sand. Although sand is a rock mass, two remaining premises are not fulfilled. In this case, when the heaps of sand were located outside the mine working, it cannot be stated that movement of rock masses took place, because according to the legal definition, movement can take place only within mine working. There was also no adopted local spatial development plan for mining land. The Court decides that classification for heaps of sand, remained after closing of mining plant several years ago, cannot be done on the base of the operational plan of that closed mining plant. Therefore, this claim is dismissed, also Supreme Administrative Court dismisses the cassation complaint ${ }^{48}$. It seems that one has to agree with the above mentioned judgments and their classification for the heaps of sand as extractive waste.

Also the decision made by the Court in the judgment of Voivodship Administrative Court in Gdańsk of $19^{\text {th }}$ July $2017^{49}$ should be found to be correct. Both the Court and the administrative authority of the second instance criticize the part of the substantiation of the decision issued by the administrative authority of the first instance, in which this administrative authority refer to the exception of applying the Act on Waste to the sand, which was purchased and stored on estate. The court states that sand bought in gravel pit and brought to the estate is not excluded from the scope of the Act on Waste, on the basis of article 2 point $11 \mathrm{AW}$ (which is identical to the exception from the Act on Extractive Waste), because it is not managed in connection with extraction of minerals from deposit within mine working, in the meaning of Geological an Mining Law. This sand was bought in gravel pit and is stored on the land of other use.

On the occasion of these reflections, it can be added that in the Italian Republic extractive waste is subject to the provisions of the legislative decree No. 117 of $30^{\text {th }}$ May $2008^{50}$. According to the definition from this

${ }^{48}$ Judgment of Supreme Administrative Court of $25^{\text {th }}$ January 2017, II OSK 1147/15. January 14, 2018http://orzeczenia.nsa.gov.pl/doc/908BDD4EFF.

${ }^{49}$ II SA/Gd 308/17, Legalis number 1650044.

${ }^{50}$ Decreto Legislativo 30 maggio 2008, n. 117, Attuazione della direttiva 2006/21/CE relativa alla gestione dei rifiuti delle industrie estrattive e che modifica la direttiva 2004/35/ CE, Gazzetta Ufficiale n. 157 del 7 luglio 2008. 
act, extractive waste is waste produced during prospecting or conducting researches, extraction, treatment and storage of mineral resources and quarrying. Concerning the concept of waste, this Act refers to the definition from the Italian environmental code $^{51}$, which is a reflection of the definition from the Directive on Waste. What is interesting, Italian implementation of the Directive on Waste is more correct, because, according to article 185 item 2 point d) of the Italian environmental code, provisions of the Part four of this code do not apply to extractive waste.

\section{CONCLUSION}

To sum up, despite the change of legislation and introduction of new Acts, provisions concerning extractive waste are still causing interpretative doubts and they are still creating problems in practice. Because of the vagueness of some concepts and the lack of some legal definition, sometimes it is hard to classify some substance or object as extractive waste. Still the legal status of certain soil and rock masses is unclear.

What is more, careless legislative technique in certain cases precludes correct interpretation of provisions from the Act on Extractive Waste ${ }^{52}$. Successive amendments have only barely improved this situation, but sometimes they even lead to currently obligatory provisions being more complicated.

\section{REFERENCES}

Barczak Anna, Kaźmierska-Patrzyczna Aneta, 2014, "Gospodarowanie odpadami w górnictwie", In: Prawna regulacja geologii i górnictwa w Polsce, Czechach i na Słowacji. Wybrane zagadnienia, ed. Grzegorz Dobrowolski, 229-239, Katowice: [Infomax, Marasik-Bielejec, E., Bielejec, G.]

${ }^{51}$ Codice dell'ambiente, Decreto legislativo, 3 aprile 2006 n. 152, Norme in materia ambientale, G. U. n. 88 del 14 aprile 2006.

${ }^{52}$ Aleksander Lipiński, Nowe..., 91. 
Bukowski Zbigniew, 2014, Prawo gospodarki odpadami, Poznań: Polskie Zrzeszenie Inżynierów i Techników Sanitarnych. Oddział Wielkopolski

Dobrowolski Grzegorz, 2013, "Rozwój ustawodawstwa dotyczącego odpadów innych niż komunalne", "Przegląd Prawa Ochrony Środowiska" 3: 9-28

Dobrowolski Grzegorz, 2006, "Skała płonna jako szczególny rodzaj odpadu”, In: Prawo i polityka w ochronie środowiska: studia z okazji 40-lecia pracy naukowej Jerzego Sommera, ed. Halina Lisicka, 71-80, Wrocław: Wydaw. Prawa Ochrony Środowiska

Draniewicz Bartosz, 2006, "Własność odpadów w prawie polskim - analiza prawna", "Przegląd Ustawodawstwa Gospodarczego" 11: 24-28

Gapiński Wojciech, 2011, "Pojęcie odpadu wydobywczego - analiza prawna", "Bezpieczeństwo Pracy i Ochrona Środowiska w Górnictwie" 1: 14-22

Jerzmański Jan, "Status prawny mas ziemnych i skalnych w Polsce oraz UE", In: Prawna regulacja geologii i górnictwa w Polsce, Czechach i na Słowacji. Wybrane zagadnienia, ed. Grzegorz Dobrowolski, 262-267, Katowice: [Infomax, Marasik-Bielejec, E., Bielejec, G.]

Korzeniowski Piotr, 2014, "Model prawny systemu gospodarki odpadami. Studium administracyjno-prawne", Łódź: Wydawnictwo Uniwersytetu Łódzkiego Lipiński Aleksander, 2016, "Zakres i przedmiot Prawa geologicznego i górniczego", In: Zrównoważony rozwój jako czynnik determinujący prawne podstawy zarządzania geologicznymi zasobami środowiska, ed. Grzegorz Dobrowolski, 37-53, Katowice: Agencja Reklamowa TOP

Lipiński Aleksander, 2017, "Komentarz do art. 6 - 9 ustawy z dnia 9 czerwca 2011 r. Prawo geologiczne i górnicze”, „Prawne problemy górnictwie i ochrony środowiska" 1: 11-33

Lipiński Aleksander, Mikosz Ryszard, 2003, Komentarz. Ustawa prawo geologiczne i górnicze, Warszawa: Dom Wydawniczy ABC

Lipiński Aleksander, 2008, "Nowe zasady postępowania z odpadami wydobywczymi" In: Aktualne problemy prawa ochrony środowiska 2008, ed. Grzegorz Dobrowolski, 91-101, Katowice: Ecausa

Mostowska Aneta (ed.), 2014, Ustawa o odpadach. Komentarz, Warszawa: C.H. Beck

Pacek-Łopalewska Aneta, 2013, Ustawa o odpadach. Komentarz, Wrocław: Presscom Sp. z o.o.

Radecki Wojciech, 2016, Ustawa o odpadach. Komentarz, Warszawa: Wolters Kluwer

Rakoczy Bartosz, 2013, In: Ustawa o odpadach. Komentarz, ed. Bartosz Rakoczy, Warszawa: LexisNexis Polska Sp. z o.o. 
Schwarz Hubert, 2012, Prawo geologiczne i górnicze. Komentarz. Vol. 1 (art. 1-103), Wrocław: Salome

Stachowski Maciej, 2014, "Gospodarka odpadami wydobywczymi", "Kruszywa" 4: 40-45

Szymczak Mieczysław (ed.), 1981, Słownik języka polskiego, Warszawa 